\title{
Pengendalian Penyakit Hawar Daun Phytophthora pada Bibit Kakao dengan Trichoderma asperellum
}

\section{Control of Phytophthora Leaf Blight Disease on Cacao Seedling Using Trichoderma asperellum}

\author{
Asti Irawanti Azis ${ }^{1 *}$, Ade Rosmana ${ }^{2}$, Vien Sartika Dewi ${ }^{2}$ \\ ${ }^{1}$ Universitas Hasanuddin, Makasar 90245 \\ ${ }^{2}$ Cocoa Research Group, Fakultas Pertanian, Universitas Hasanuddin, Makassar 90245
}

\begin{abstract}
ABSTRAK
Penyakit hawar daun Phytophthora yang disebabkan oleh Phytophthora palmivora merupakan salah satu kendala di pembibitan kakao di Indonesia. Pengendalian penyakit ini umumnya menggunakan fungisida sintetik, namun dampak negatif dari penggunaan fungisida sintetik ini mulai dirasakan. Penelitian dilakukan dengan tujuan menguji kemampuan dua isolat Trichoderma asperellum (ARBT-1 dan ART-4) menekan perkembangan penyakit hawar daun tersebut. Kedua isolat diaplikasikan melalui perlakuan benih dengan konsentrasi spora $10^{4} \mathrm{~mL}^{-1}, 10^{5} \mathrm{~mL}^{-1}$ dan $10^{6} \mathrm{~mL}^{-1}$. Intensitas penyakit dengan perlakuan konsentrasi spora tersebut berturut-turut adalah $39.0 \%, 23.6 \%$, dan $21.8 \%$ untuk isolat ARBT-1 dan 30.6\%, 25.7\%, dan 30.8\% untuk isolat ART-4, sedangkan pada perlakuan kontrol mencapai $90.3 \%$ pada 21 hari setelah inokulasi dengan patogen. Pengamatan jaringan daun setelah perlakuan menunjukkan bahwa kedua isolat $T$. asperellum ditemukan di dalam jaringan, menandakan sifatnya sebagai cendawan endofit.
\end{abstract}

Kata kunci: cendawan antagonis, pembibitan, perlakuan benih

\begin{abstract}
Phytophthora leaf blight caused by Phytophthora palmivora is one constraint in cacao seedling in Indonesia. Generally, synthetic fungicides were applied to control this disease but its negative impact is becoming obvious recently. Research was conducted to evaluate the effectiveness of two Trichoderma asperellum isolates, ARBT-1 and ART-4, to suppress disease development. The two isolates were applied through seed treatment with spore concentrations of $10^{4} \mathrm{~mL}^{-1}, 10^{5} \mathrm{~mL}^{-1}$, and $10^{6} \mathrm{~mL}^{-1}$. The results showed that disease incidence on seedling treated with different spore concentrations of ARBT- 1 was $39.0 \%, 23.6 \%$, and $21.8 \%$, respectively and those with ART- 4 was $30.6 \%, 25.7 \%$, and $30.8 \%$, respectively, whereas disease incidence reached $90.3 \%$ for control at 21 days after inoculation of the pathogen. Observations on cocoa leaf tissues showed that the two isolates were found in leaf tissue, indicating that T. asperellum is an endophyte.
\end{abstract}

Key words: antagonistic fungi, seedling, seed treatment

*Alamat penulis korespondensi: Jurusan Proteksi Tanaman, Fakultas Pertanian, Universitas Hasanuddin, Jalan Perintis Kemerdekaan Km.10, Makassar 90245

Tel: 0411-586477, Faks: 0411-586477, Surel: astiazis@ymail.com 


\section{PENDAHULUAN}

Penyakit memegang peranan penting dalam penurunan produktivitas tanaman kakao. Phytophthora palmivora adalah salah satu penyebab penyakit yang dikenal dengan penyakit busuk buah, kanker batang, dan busuk pucuk di pertanaman kakao di lapang serta juga penyakit hawar daun di pembibitan di Indonesia. Penyakit yang terakhir dapat menyebabkan daun-daun menjadi kering dan kematian bibit terutama yang berumur 1-2 bulan. Oleh karena itu, penyakit bibit ini perlu mendapat perhatian dan pengendalian secara dini untuk mengurangi kerugian yang ditimbulkannya.

Pengendalian yang umum dilakukan sampai sejauh ini adalah dengan menggunakan fungisida sintetik. Frekuensi aplikasi dan konsentrasi pestisida yang tinggi ditujukan agar penyakit hawar daun terkendali dengan baik. Hal ini tentu saja berdampak negatif bagi kesehatan, menimbulkan pencemaran lingkungan, dan gangguan keseimbangan ekologis. Berdasarkan pada hal tersebut, perhatian dalam mencari alternatif pengendalian, terutama dengan pengendalian hayati semakin besar. Pengendalian hayati merupakan bagian dari pengelolaan hama dan penyakit terpadu (PHPT) yang dirancang untuk menyeimbangkan dan mengelola kegiatan yang berhubungan dengan daur pertanaman, serta memaksimalkan keuntungan petani dengan memperbaiki kesehatan tanaman.

Banyak peneliti memanfaatkan mikroorganisme antagonis sebagai agens yang efektif untuk mengendalikan berbagai patogen secara hayati. Penggunaan cendawan Trichoderma spp. untuk mengendalikan penyakit yang disebabkan Phytophthora spp. cukup potensial. Menurut pengujian yang dilakukan oleh Rosmana et al. (2006), efikasi Trichoderma yang diaplikasikan melalui penyemprotan pada buah kakao setara dengan fungisida kuprik oksida dalam mengurangi penyakit busuk buah Phytophthora. Salah satu spesies Trichoderma, yaitu T. asperellum diduga memiliki kemampuan antagonis yang dapat menekan perkembangan $P$. palmivora yang menyebabkan penyakit hawar daun pada pembibitan kakao. Oleh karena itu, penelitian ini dilakukan dengan tujuan untuk menganalisis dampak dari dua isolat $T$. asperellum pada tingkat konsentrasi spora yang berbeda terhadap perkembangan penyakit hawar daun Phytophthora.

\section{BAHAN DAN METODE}

\section{Pembuatan Suspensi Isolat T. asperellum}

Biakan murni $T$. asperellum isolat ARBT-1 dan ART-4 diperoleh dari koleksi cendawan endofit milik Dr Ir Ade Rosmana di Laboratorium Cocoa Research Group, Fakultas Pertanian, Universitas Hasanuddin. Koloni cendawan yang telah diremajakan pada medium PDA di dalam cawan Petri yang berumur 5 hari dimasukkan ke dalam labu erlenmeyer yang berisi $100 \mathrm{~mL}$ akuades, kemudian dihomogenkan dan disaring. Suspensi spora hasil saringan diambil sebanyak $1 \mathrm{~mL}$ dengan pipet ukur, kemudian dihitung konsentrasi sporanya pada hemositometer dengan menggunakan mikroskop.

\section{Perlakuan Benih dengan T. asperellum dan Penanaman Bibit Kakao Uji}

Benih kakao klon M-01 yang diuji direndam pada suspensi spora dua isolat $T$. asperellum (ARBT-1 dan ART-4) masing masing dengan konsentrasi $10^{4} \mathrm{~mL}^{-1}, 10^{5} \mathrm{~mL}^{-1}$ dan $10^{6} \mathrm{~mL}^{-1}$ selama 2 jam. Sebagai kontrol, benih kakao direndam pada air steril, juga selama 2 jam.

Benih yang telah diberi perlakuan dikecambahkan pada kain lembab steril. Setelah berumur 6 hari, bibit yang telah berkecambah dan memiliki pertumbuhan yang seragam dipindahkan ke kantong plastik berdiameter $17 \mathrm{~cm}$ dan tinggi $25 \mathrm{~cm}$ yang berisi media campuran tanah dan pupuk kandang, kemudian disimpan di dalam rumah kaca, Fakultas Pertanian, Universitas Hasanuddin.

\section{Inokulasi $P$. palmivora pada Bibit Kakao Uji}

P. palmivora dibiakkan pada buah kakao. Buah kakao yang berumur kurang lebih 3 bulan 
disterilkan permukaannya dengan etanol 70\%. Setelah dibiarkan selama 1-2 menit, buah ini dibilas secara berulang dengan akuades steril, kemudian dikeringanginkan dalam kondisi steril. Buah selanjutnya diinokulasi dengan spora $P$. palmivora yang diperoleh dari buah terinfeksi di lapang dan seluruh permukaan buah dilapisi dengan plastik tipis steril untuk menghindari kontaminasi kemudian ditempatkan pada kondisi lembab agar $P$. palmivora berkembang dengan baik. Setelah diinkubasikan selama 7 hari, miselium dan sporanya dipanen dan disuspensikan dalam akuades steril. Bibit kakao yang berumur 27 hari diinokulasi melalui penyemprotan suspensi yang mengandung $10^{6} \mathrm{spora} / \mathrm{mL}$.

\section{Pengamatan Keparahan Penyakit Hawar Daun Phytophthora}

Pengamatan penyakit hawar daun Phytophthora mulai dilakukan pada 7 hari setelah inokulasi (HSI) dan pengamatan ini diulang setiap 2 sampai 21 HSI. Tingkat keparahan penyakit ini pada bibit kakao dihitung dengan menggunakan rumus:

$$
\mathrm{KP}=\mathrm{n} / \mathrm{N} \times 100 \% \text {, dengan }
$$

$\mathrm{n}$, jumlah tanaman bergejala; $\mathrm{N}$, total jumlah tanaman uji.

\section{Pengamatan Keberadaan $T$. asperellum dalam Jaringan Daun}

Untuk mengetahui keberadaan isolat ARBT-1 dan ART-4 dalam jaringan daun, bibit yang diinokulasi dengan konsentrasi tertinggi diambil daunnya. Daun sampel tersebut diiris tipis dan diamati di bawah mikroskop setelah diwarnai dengan lactophenol blue. Pengamatan dilakukan setelah pengamatan terakhir intensitas penyakit hawar daun Phytophthora.

\section{Rancangan Percobaan dan Analisis Data}

Percobaan disusun berdasarkan rancangan acak lengkap dengan perlakuan $T$. asperellum isolat ARBT-1 dengan konsentrasi $10^{4} \mathrm{~mL}^{-1}$, $10^{5} \mathrm{~mL}^{-1}$ dan $10^{6} \mathrm{~mL}^{-1}$ serta isolat ART-4 dengan konsentrasi $10^{4} \mathrm{~mL}^{-1}, 10^{5} \mathrm{~mL}^{-1}$ dan $10^{6} \mathrm{~mL}^{-1}$. Setiap perlakuan diulang sebanyak
4 kali. Uji beda nyata data intensitas serangan ditransformasi pada akar kuadrat $(\sqrt{ } \mathrm{x}+1)$. Hasil analisis yang diperoleh dilakukan uji lanjut BNT.

\section{HASIL}

\section{Gejala Penyakit}

Daun bibit kakao yang diinokulasi $P$. palmivora memperlihatkan gejala hawar, seperti terbakar yang dimulai dari tepi daun. Gejala ini tampak jelas terutama pada bibit yang tidak diaplikasi dengan $T$. asperellum atau kontrol dan mulai muncul pada 7 HSI. Infeksi patogen lebih lanjut pada kontrol menyebabkan daun mati (Gambar 1). Padabibit yang sebelumnya diinokulasi $T$. asperellum, gejala muncul secara umum pada 9 HSI.

\section{Intensitas Penyakit}

Perlakuan T. asperellum baik isolat ARBT-1 maupun ART-4 menekan intensitas penyakit hawar daun Phytophthora. Intensitas penyakit dengan perlakuan konsentrasi suspensi spora $T$. asperellum $10^{4} \mathrm{~mL}^{-1}, 10^{5} \mathrm{~mL}^{-1}$, dan $10^{6} \mathrm{~mL}^{-1}$ dengan isolat ARBT-1 masing- masing adalah 3.1\%, 2.8\%, dan 3.6\% serta dengan isolat ART-4 masingmasing $0 \%, 6.3 \%$, dan $10.3 \%$ pada 9 HSI. Kemudian menjadi masing-masing 39.0\%, $23.6 \%$, dan $21.8 \%$ dengan isolat ARBT-1 serta masing-masing $30.6 \%, 25.7 \%$, dan $30.8 \%$ dengan isolat ART-4 pada 21 HSI patogen, sedangkan pada kontrol, intensitas penyakit mencapai $61.4 \%$ dan $90.3 \%$ pada 9 HSI dan 21 HSI (Tabel 1).

Perlakuan kedua isolat pada semua konsentrasi di atas terhadap intensitas penyakit berbeda nyata ( $\alpha 0.01)$ dengan kontrol pada semua pengamatan dari 7 sampai $21 \mathrm{HSI}$, sedangkan antara dua isolat, perbedaan nyata $(\alpha 0.01)$ terlihat pada 21 HSI ketika intensitas penyakit yang diberi perlakuan dengan isolat ARBT-1 lebih rendah bila dibandingkan dengan isolat ART-4. Perbedaan nyata antara perlakuan konsentrasi suspensi spora juga terlihat pada 21 HSI dengan isolat ARBT-1, sedangkan pada isolat ART-4 tidak memperlihatkan perbedaan nyata. 


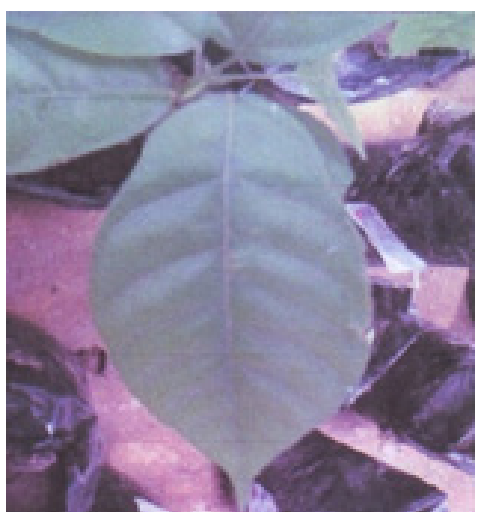

a

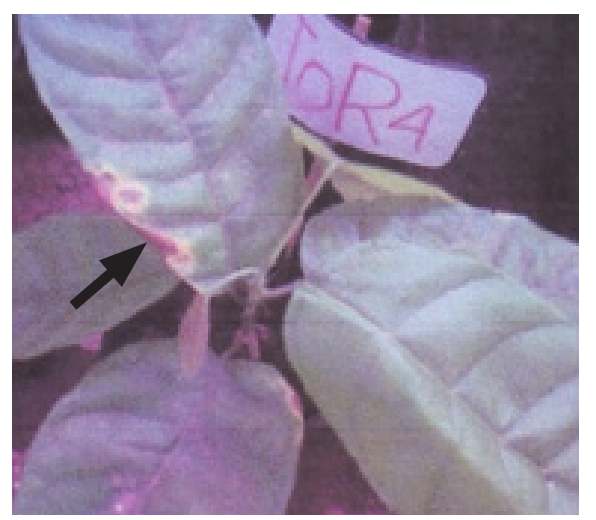

$\mathrm{b}$

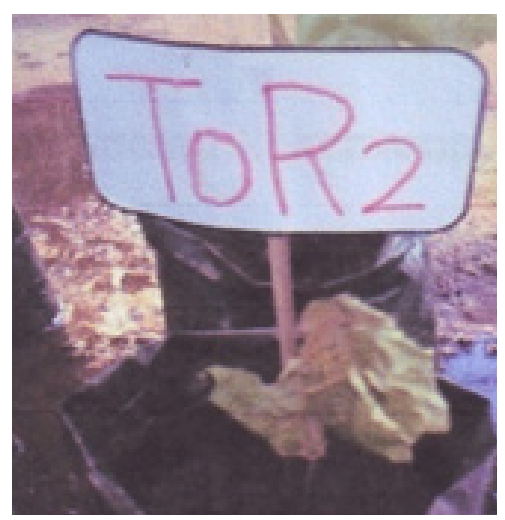

C

Gambar 1 Bibit tanaman kakao. a, Diberi perlakuan Trichoderma asperellum, tanpa gejala hawar daun Phytophthora; b, Tanpa perlakuan (kontrol), gejala hawar daun Phytophthora yang dimulai dari tepi daun; dan c, Tanpa perlakuan (kontrol), tanaman mati.

Tabel 1 Intensitas penyakit hawar daun Phytophthora (\%) pada bibit kakao yang diberi perlakuan Trichoderma asperellum isolat ARBT-1 dan ART-4 dengan 3 konsentrasi berbeda melalui perlakuan benih pada hari setelah inokulasi

\begin{tabular}{|c|c|c|c|c|c|c|c|c|c|}
\hline \multirow{2}{*}{ Isolat } & \multirow{2}{*}{ Konsentrasi } & \multicolumn{8}{|c|}{ Intensitas penyakit pada hari setelah inokulasi (\%) } \\
\hline & & 7 & 9 & 11 & 13 & 15 & 17 & 19 & 21 \\
\hline Kontrol & 0 & $24.9 \mathrm{a}$ & $61.4 \mathrm{a}$ & $70.8 \mathrm{~b}$ & $74.7 \mathrm{a}$ & $79.2 \mathrm{a}$ & $84.4 \mathrm{a}$ & $85.4 \mathrm{a}$ & $90.3 \mathrm{a}$ \\
\hline \multirow[t]{3}{*}{ ARBT-1 } & $10^{4}$ & 0 & $3.1 \mathrm{~b}$ & $9.7 \mathrm{~b}$ & $12.5 \mathrm{~b}$ & $26.1 \mathrm{~b}$ & $28.5 \mathrm{~b}$ & $32.9 \mathrm{~b}$ & $39.0 \mathrm{~b}$ \\
\hline & $10^{5}$ & $0 \mathrm{~b}$ & $2.8 \mathrm{~b}$ & $2.8 \mathrm{~b}$ & $5.6 \mathrm{~b}$ & $5.6 \mathrm{c}$ & $11.5 \mathrm{~b}$ & $14.6 \mathrm{c}$ & $23.6 \mathrm{c}$ \\
\hline & $10^{6}$ & $0 \quad \mathrm{~b}$ & $3.6 \mathrm{~b}$ & $9.4 \mathrm{~b}$ & $12.5 \mathrm{~b}$ & $16.1 \mathrm{~b}$ & $16.1 \mathrm{~b}$ & $14.7 \mathrm{c}$ & $21.8 \mathrm{c}$ \\
\hline \multirow[t]{3}{*}{ ARBT-4 } & $10^{4}$ & $0 \quad \mathrm{~b}$ & $0 \mathrm{~b}$ & $0 \quad \mathrm{c}$ & $2.8 \mathrm{~b}$ & $5.3 \mathrm{c}$ & $10.6 \mathrm{c}$ & $21.1 \mathrm{~b}$ & $30.6 \mathrm{~b}$ \\
\hline & $10^{5}$ & $0 \quad b$ & $6.3 \mathrm{~b}$ & $15.2 \mathrm{~b}$ & $16.3 \mathrm{~b}$ & $16.3 \mathrm{~b}$ & $17.1 \mathrm{~b}$ & $16.4 \mathrm{c}$ & $25.8 \mathrm{~b}$ \\
\hline & $10^{6}$ & $0 \quad b$ & $10.3 \mathrm{~b}$ & $12.5 \mathrm{~b}$ & $15.6 \mathrm{~b}$ & $15.6 \mathrm{~b}$ & $20.5 \mathrm{~b}$ & $18.8 \mathrm{c}$ & $30.9 \mathrm{~b}$ \\
\hline
\end{tabular}

Angka-angka dalam kolom yang sama yang diikuti oleh huruf yang sama tidak berbeda nyata pada taraf $1 \%$.

Pengamatan T. asperellum dalam Jaringan Daun

Pengamatan T. asperellum pada jaringan daun (Gambar 2) menunjukkan bahwa isolat ARBT-1 dan ART-4 diamati keberadaannya dengan jelas dalam jaringan daun dan hasil tersebut membuktikan bahwa kedua isolat adalah endofit.

\section{PEMBAHASAN}

Bibit kakao uji yang diinokulasi dengan $P$. palmivora memperlihatkan gejala spesifik seperti dilaporkan McMahon dan Purwantara (2004). Perlakuan perendaman biji kakao dengan dua isolat $T$. asperellum ARBT-1 dan ART-4 menekan intensitas penyakit hawar daun Phytophthora. Ini membuktikan bahwa perendaman biji dengan kedua isolat di atas sebelum dilakukan pembibitan relatif efektif. Rachmawaty et al. (1995) menyatakan bahwa pemberian inokulum cendawan antagonis lebih awal memungkinkan cendawan memperbanyak diri dan menyesuaikan diri dengan lingkungan tanaman.

Pengamatan pada daun menunjukkan keberadaan kedua isolat $T$. asperellum pada jaringan daun bibit kakao, hal ini membuktikan bahwa isolat ARBT-1 dan ART-4 adalah endofit serta fenomena endofit ini diamati pula oleh Rosmana et al. (2013). Tampaknya $T$. asperellum yang melapisi permukaan biji kakao menembus jaringan tanaman melalui akar, kemudian masuk batang dan jaringan daun. Studi akhirakhir ini menunjukkan bahwa dalam 


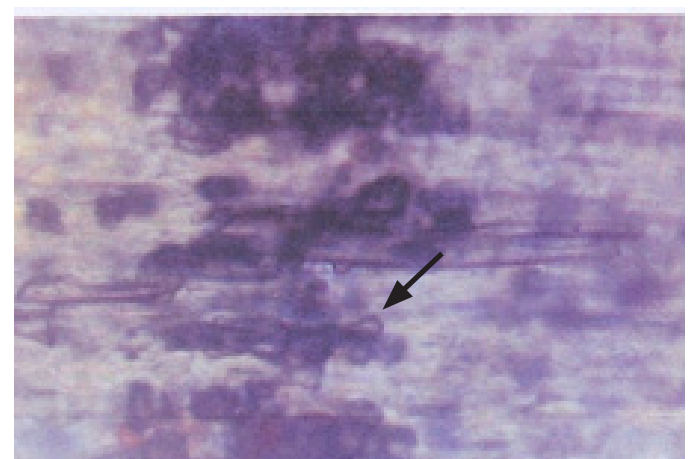

a

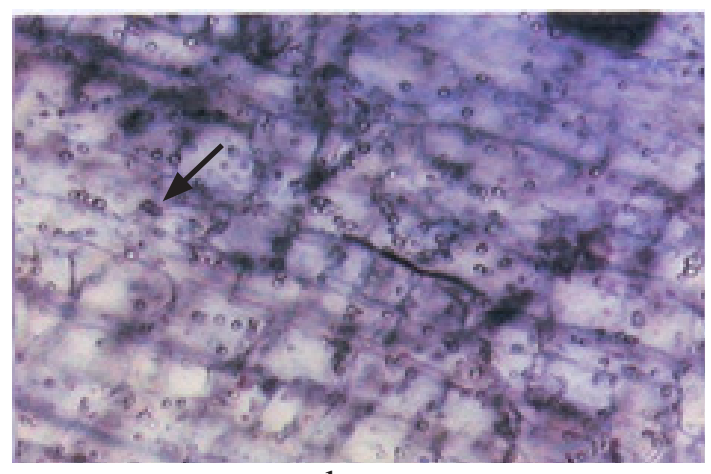

b

Gambar 2 Pengamatan mikroskopik spora Trichoderma asperellum dengan pewarnaan pada jaringan batang kakao. a, Perbesaran 40 kali; b, Perbesaran 10 kali.

asosiasi jaringan kakao dan Trichoderma, Trichoderma juga dapat melakukan penetrasi ke dalam jaringan tanaman kakao melalui trikom (Bailey et al. 2009). Trikom adalah sel epidermis yang dimodifikasi menyerupai rambut akar dan terdapat dalam dua bentuk, yaitu trikom glandular dan nonglandular (Ishida 2008). Keberadaan T. asperellum pada jaringan daun memungkinkan $P$. palmivora tidak mengolonisasi jaringan ini sehingga perkembangan gejala hawar daun dihambat.

Cara kerja isolat $T$. asperellum dalam menghambat perkembangan penyakit hawar daun Phytophthora belum diketahui dengan pasti. Studi in vitro dengan Trichoderma spp. endofit lainnya pada kakao, seperti $T$. hamatum dan T. harzianum, memperlihatkan bahwa cendawan memproduksi metabolit yang bersifat toksik dan bersifat parasit terhadap Moniliophthora roreri dan P. capsici pada medium kultur (Bailey et al. 2008). Kolonisasi cendawan endofit kakao lainnya, T. stilbohypoxyli pada cabai dapat menginduksi ekspresi pengenal yang berhubungan dengan pertahanan, termasuk berbagai protein lipid transferase (PLT). Selain protein ini, gen yang ikut serta dalam respons hipersensitif, biosintesis fitoaleksin seskuiterpen, serta gen yang berperan dalam metabolisme hormon, seperti etilena, asam salisilik, asam jasmonik, dan asam giberelik juga diinduksi (Bae et al. 2011).

Penelitian ini mengungkap cara yang efektif dan efisien dalam pengendalian penyakit hawar daun Phytophthora pada pembibitan, yaitu melalui perlakuan benih dengan T. asperellum endofit. Disimpulkan efektif karena pada hasil ditunjukkan bahwa penggunaan dua isolat $T$. asperellum dapat mengendalikan penyakit secara nyata, dan efisien karena perlakuan hanya dilakukan satu kali, yaitu pada benih sebelum ditanam, tidak dilakukan secara berulang. Kedua isolat T. asperellum tampak relatif persisten dalam jaringan bibit kakao selama kurang lebih dua bulan penelitian.

\section{DAFTAR PUSTAKA}

Bae H, Roberts DP, Lim HS, Strem MD, Park SC, Ryu CM, Melnick RL, Bailey BA. 2011. Endophytic Trichoderma isolates from tropical environments delay disease onset and induce resistance against Phytophthora capsici in hot pepper using multiple mechanisms. Mol Plant Microbe Interact. 24(3):336-351. DOI: http:// dx.doi.org/10.1094/MPMI-09-10-0221.

Bailey BA, Bae H, Strem MD, Crozier J, Thomas SE, Samuels GJ, Vinyard BT, Holmes KA. 2008. Antibiosis, mycoparasitism and colonization success for endophytic Trichoderma isolates with biological control potential in Theobroma cacao. J Biol Control. 46(1):24-35. DOI: http://dx.doi. org/10.1016/j.biocontrol.2008.01.003.

Bailey BA, Strem MD, Wood D. 2009. Trichoderma species form endophytic associations within Theobroma cacao trichomes. Mycol Res. 113(12):13651376. DOI: http://dx.doi.org/10.1016/j. mycres.2009.09.004. 
Ishida $\mathrm{T}$, Kurata $\mathrm{T}$, Okada $\mathrm{K}$, Wada $\mathrm{T}$. 2008. A genetic regulatory network in development of trichomes and root hairs. Annu Rev Plant Biol. 59:365-386. DOI: http://dx.doi.org/10.1146/annurev. arplant.59.032607.092949.

McMahon P, Purwantara A. 2004. Phytophthora on cocoa. Di dalam: Drenth A, Guest DI, editor. Diversity and Management of Phytophthora in Southeast Asia. Canbera (AU): ACIAR Monograph. hlm 104-115.

Rachmawaty A, Ambarwati, Toekidjo M. 1995. Kajian pengendalian penyakit busuk batang vanili dengan Trichoderma viridae. Di dalam: Prosiding Kongres Nasional XIII dan Seminar Ilmiah Perhimpunan Fitopatologi Indonesia; 1995 Sep 25-27;
Mataram (ID): PFI Komda Nusa Tenggara Barat. hlm 207-210.

Rosmana A, Sahrani E, Saharuddin W, Junaid M. 2006. Comparison of Trichoderma use with synthetic fungicide to control Phytophthora pod rot of cocoa. Fitomedika. 6:22-25.

Rosmana A, Samuel GJ, Ismaiel A, Ibrahim ES, Chaverri P. Herawati Y, Asmana. 2013. Trichoderma asperellum, a dominant endophyte species from cocoa environments of Sulawesi with potential for controlling vascular streak dieback disease. Di dalam: Program and Abstract of Sulawesi International Seminar on Cocoa; 2013 Jun 26-28; Makassar (ID): Cocoa Research Group, Universitas Hasanuddin. hlm. 22. 